\title{
MYC Family Protein
}

National Cancer Institute

\section{Source}

National Cancer Institute. MYC Family Protein. NCI Thesaurus. Code C18538.

MYC family proteins exhibit sequence homology with the transcription factor MYC protooncogene. 